\title{
Distal Urethral Carcinoma
}

National Cancer Institute

\section{Source}

National Cancer Institute. Distal Urethral Carcinoma. NCI Thesaurus. Code C115210.

A carcinoma that arises from the distal part of the urethra. 